\title{
Area and Seedlings Demand Forecast of Cabbage and Economics of Nurseries in Karnataka
}

\author{
Ashoka, $\mathrm{N}^{1 *}$., Ravi, $\mathrm{Y}^{2}$., Ravi Kumar, B. ${ }^{3}$, Lingamurthy, K.R. ${ }^{4}$ and Anupama, G. ${ }^{5}$
}

${ }^{1}$ Assistant Professor of Agricultural Economics, College of Horticulture, Munirabad, Koppal, Karnataka, India

${ }^{2}$ Scientist, ICAR-National Research Centre on Seed Spices, Ajmer, Rajasthan, India

${ }^{3}$ Assistant Professor of Plant Pathology, College of Horticulture, Munirabad, Koppal, Karnataka, India

${ }^{4}$ Assistant Professor of Vegetable Science, College of Horticulture, Munirabad, Koppal, Karnataka, India

${ }^{5}$ Assistant Horticulture Officer, Horticulture Training Centre, Munirabad, Koppal, Karnataka, India

*Corresponding author: ashokan.abm@gmail.com (ORCID ID: 0000-0003-4952-1803)

Received: $11-04-2019$

Revised: $16-07-2019$

Accepted: 24-08-2019

\begin{abstract}
India is the second largest producer of vegetables in the world next to China. The cabbage is the major vegetable crop of Karnataka. The study was conducted in Belagavi, Haveri and Kolar districts to analyze cost and returns of seedling rising in nursery under shade net condition. This study also attempts to estimate the area under cultivation of cabbage in Karnataka and also to forecast the demand for cabbage seedlings during 2019-20. The results indicated that the area under cabbage cultivation estimated to be 11263 hectare and the demand for cabbage seedlings are 62.57crores in the state of Karnataka for the agricultural year 2019-20. The analysis of the study indicated that, the nursery entrepreneurs have invested ₹ 265977 towards setting up of nursery in an area of $1000 \mathrm{~m}^{2}$ under shade net on their own. The economic analysis pointed out that entrepreneurs have realized gross income of ₹ 248920 and net returns of ₹ 77383 per time. The capital investment on cabbage nursery was found to be economically viable in terms of Net Present Worth (₹ 119836), Benefit Cost Ratio (1.30) and Internal Rate of Returns (78\%).

\section{Highlights}

( The area under cabbage cultivation estimated to be 11263 hectare and the demand for cabbage seedlings are 62.57 crores.

( The entrepreneurs have realized gross income of ₹ 248920 and net returns of ₹ 77383 per time in $1000 \mathrm{~m}^{2}$ shade net area.
\end{abstract}

Keywords: cabbage, area, seedling, demand,nursery, economics and profit

Cabbage is the second most important crop of the cole group in India. Barring one or two months of intense heat, it is produced through out the year. The word cabbage was derived Cabbage is the second most important crop of the cole group in India. Barring one or two months of intense heat, it is produced through out the year. The word cabbage was derived Cabbage is the second most important crop of the cole group in India. Barring one or two months of intense heat, it is produced through out the year. The word cabbage was derived Cabbage is known as one of the ancient vegetable crops. It has been used as a food crop for more than 3000 years and was revered by the Greeks for its many medicinal properties Cole crops' is a general term used to describe several vegetables in the mustard family.

This group of vegetables includes cauliflower, cabbage, knol-khol, broccoli, Brussels sprouts, kale and Chinese cabbage (see under leafy and salad vegetables). All the crops are cultivated varieties of the species Brassica oleracea.

Cole crops is a general term used to describe several vegetables in the mustard family. This group of 
vegetables includes cauliflower, cabbage, knolkhol, broccoli, Brussels sprouts, kale and Chinese cabbage (see under leafy and salad vegetables). All the crops are cultivated varieties of the species Brassica oleracea. While cauliflower and cabbage are regarded as majorvegetables, the rest especially in India are considered minor vegetables (Dhaliwal, 2017). Cabbage (Brassica oleracea L. var. capitata) is known as one of the ancient vegetable crops, it has from a wild non heading type, 'Cole wart' (Brassica oleracea var. sylvestris). It has been used as a food crop for more than 3000 years and was revered by the Greeks for its many medicinal properties. Cabbage is the second most important crop of the cole group in India. Barring one or two months of intense heat, it is produced throughout the year. The word cabbage was derived from the French word 'caboche', meaning head. The Latin name Brassica was derived from the Celtic word 'bresic' also meaning cabbage. Normally it is consumed after cooking and also fresh vegetable in salads. It is stewed with onion andpotato. Thinly sliced heads are sautéed or stir fried. The finely cut head shreds are used as agarnish for sandwiches. Stuffed cabbage is a favourite throughout Eastern Europe and Turkey (Dhaliwal, 2017). It is an important source of vitamins, especially $A, C$ and $B$, and minerals, especially calcium and potassium. It provides the roughage that prevents constipation. Per 100 g edible part of cabbage contains 91.9 percent moisture, $4.6 \mathrm{~g}$ carbohydrates, $1.8 \mathrm{~g}$ protein, $0.1 \mathrm{~g}$ fat, $1200 \mu \mathrm{g} \beta$-carotene, $0.06 \mathrm{mg}$ thiamine, 0.09 $\mathrm{mg}$ riboflavin, $124 \mathrm{mg}$ vitamin C, $39 \mathrm{mg}$ calcium and $0.8 \mathrm{mg}$ iron. It has been ranked by the food and Agriculture Organization among the top twenty vegetable crops grown worldwide, establishing it as an important food source globally (Food and Agriculture organization, 1998).

Quality seed and seedlings are the foundation of bumper harvest to meet the requirement of $300 \mathrm{~g}$ vegetables per day per capita (ICMR recommendation) and also to meet the demand for fresh, export and processing industries. Hence, there is an urgent need to increase the production and productivity of vegetables through various means such as use of high quality seeds of improved varieties and hybrids, following high tech production and protection technologies. Healthy seeds and seedlings are the basic prerequisite for achieving full yield potential of any vegetable crop (Pandiyarajet al., 2017). In the era of climate change and amplified population in the country the vegetable growers have become highly conscious about prominence of quality seeds or seedlings to meet the demand and get the attractive profit. A major portion of the area under vegetable cultivationin India is now sown with hybrid seeds, which are costly but give higher yields and quality produce. In view of the high cost of seeds, cabbage vegetable are being transplanted after growing nursery under protected conditions to achieve maximum germination count and healthy plant establishment under field condition. Cabbage crop is primarily grown by small and marginal farmers and it is an important source of income for them. The crop cultivation faces several problems viz., poor field stand, inadequate field management practices, incidence of pest and diseases etc. which cause enormous yield losses. Among different problems faced by commercial cabbage growing farmer's, lack of quality seedling for direct field planting is one among them. Keeping in view of above factors, which influences the growth yield and income of vegetable growers, a study was conducted on economic status of vegetable nursery entrepreneurs and cabbage crop seedling demand for the current season in Karnataka state. The objective of the study is to assess the economics and feasibility of vegetable nursery entrepreneurship and seedling demand of cabbage crop for the present growing season in major growing districts of Karnataka state. This article intent to be better guide and may be great utility to the extension workers, vegetable growers, nursery entrepreneurs and other stakeholders.

\section{METHODOLOGY}

Availability of quality planting material is a prerequisite to the success of horticulture development initiatives. The Seeds Act and the Nursery Registration Act have been in operation since December 1966. This necessitates having a network of Horticulture Nurseries which conform to Model Nursery Standards in terms of Infrastructure, Quality of Seed and Planting Materials and adoption of Nursery Management Practices. Raising the quality seedlings is a specialized technique which requires skill and technical knowhow. The present study was taken up in the state of Karnataka 
as Karnataka is one of the leading producers of cabbage. Cabbage is cultivated in all most all districts of Karnataka. The demand of cabbage seedlings in major growing districts and state as a whole was estimated using Compound Annual Growth Rate (CAGR). The total area under this crop and per hectare requirement of seedlings was projected as per recommended package of practice (Anon., 2014). The CAGR in area was calculated with exponential model. The secondary data on area with respect to major growing districts under cabbage was collected from Directorate of Economics and Statistics, Bengaluru from 2010-11 to 2018-19 (www.des.kar.nic.in). The method of exponential model and computation of CAGR is detailed below (Sathyendra Kumar and Chandrashekar, 2015).

$$
Y_{1}=\beta_{0} \beta_{1}^{t} e^{U_{1}}
$$

$Y_{t}=$ Area under cabbage in hectares during ' $t$ ' time period in major districts and state

$$
\begin{aligned}
& \beta_{0}=\text { Intercept } \\
& \beta_{1}=\text { Slope coefficient } \\
& t=\text { Time in years (2010-11 to 2018-19) } \\
& u_{t}=\text { Stochastic term }
\end{aligned}
$$

The estimable form of the model was obtained by natural logarithmic transformation. The parameters of the model were estimated using ordinary least squares,

$$
\text { i.e., } Y_{t}=\ln \beta_{0}+\operatorname{tin} \beta_{1}+U_{t}
$$

The compound annual growth rate (CAGR) in area was obtained from the expression given as CAGR $=(\operatorname{antilog}(\ln \beta 1)-1)^{*} 100$.

The growth in area under cabbage for the subsequent year was determined by adding actual area under cabbage in the previous year with actual area times compound annual growth rate i.e., Area under cabbage in 2019-20=Area under cabbage in 2018-19 + CAGR $\times$ (Area under cabbage in 201819). For instance, the CAGR in area under cabbage for Karnataka state was 2.51 percent and the area during preceding year was 10987 hectares. The growth in area for the succeeding year will be 10987 $\times 0.0251=276$ hectares. Hence, the total area under cabbage in the succeeding year will be $10987+276=$ 11263 hectares. The demand forecast of the seedlings is estimated by considering total area in succeeding year and seedlings requirement per hectare (55555 seedlings hectare ${ }^{-1}$ at spacing of $0.60 \times 0.30 \mathrm{~m}$ ) as recommended in the package of practice, UHS, Bagalkot (Anon., 2014).

In order to meet the total demand of seedlings, nurserymen are employing modern techniques of raising seedlings are essential. In this regard, an attempt was made to examine whether investment on nurseries enterprise is economically feasible or not using project evaluation technique. In order to fulfill this objective, sample of 10 nurseries from each of the districts viz., Belagavi, Haveri and Kolar in Karnataka randomly were selected. The feasibility of investment on cabbage seedling production under shade-net structure was determined by suing discounted and undiscounted cash flow techniques (Murthy et al. 2009). The discount rate of 12 per cent was considered in the present study since it is close to opportunity cost of capital in India. The research was based on both primary and secondary data. The primary data was collected from the owners of the selected nursery entrepreneurs during the year 2019-20. The secondary data on area were collected from Directorate of Economics and Statistics, Bengaluru.

\section{Discounted cash flow measures}

Net Present Worth $(N P W)=\sum_{t=1}^{15} \frac{\beta_{t}}{(1+r)^{t}}-\sum_{t=1}^{15} \frac{C_{t}}{(1+r)^{t}}$

Benefit Cost Ratio $(B C R)=\frac{\sum_{t=1}^{15} \frac{\beta_{t}}{(1+r)^{t}}}{\sum_{t=1}^{15} \frac{C_{t}}{(1+r)^{t}}}$

where,

$B_{t}$ is the benefit stream of the project in ' $t$ ' period $C_{t}$ is the cost stream of the project in ' $t$ ' period, $r$ is the discount rate assumed as 12 per cent (opportunity cost of capital),

$t$ is the life span of the project (15 years)

Internal Rate of Return $(\mathrm{IRR})=\mathrm{LDR}+(\mathrm{HDR}-$

$\mathrm{LDR}) \times\left(\frac{N P W \text { at } L D R}{N P W \text { at } L D R+N P W \text { at } H D R}\right)$ 
LDR is lower discount rate is the discount rate which leaves positive NPW and HDR is Higher discount rate is the discount rate which leaves negative NPW.

\section{Undiscounted cash flow measures}

Pay Back Period (years) $=\frac{\text { Initial investment }}{\text { Annual net cash revenue }}$

\section{RESULTS AND DISCUSSION}

The area under cabbage in major growing districts of Karnataka and state as a whole during 201819 , estimated area under cabbage cultivation during 2019-20 and estimated demand for cabbage seedlings depicted in table 1 . The CAGR for the area under cabbage in major growing districts and Karnataka as well worked out using time series data from 2010-11 to 2018-19. This data was analyzed using compound annual growth rate. The area under cabbage in Karnataka state grown at the rate of 2.51 per cent per annum during the study period as shown in table 1. Similarly, major growing districts i.e., Belagavi, Kolar, Haveri and Chikkaballapura have registered positive and significant growth rates to the tune of 4.50, 0.60, 4.57 and 4.97 per cent per annum whereas negative growth rates was witnessed with respect to growth of area under cabbage in Bidar district $(-1.12 \%$ per annum) during the study period. Implementation of National Horticulture Mission scheme in Karnataka is the main for increase in area under cabbage crop (Patil and Hosamani, 2017). The farmers of these districts are expertise in production of cabbage as there is stable and increased demand in the market for the cabbage and are considered as one of the staple vegetable considered for their daily food menu.
Based on the CAGR for the period of 2010-11 to 2018-19, the incremental (increases/ decrease) area under cabbage worked out for major growing districts and state as well for the next year 2019-20. For Karnataka state as a whole, area under cabbage is going to increase to the tune of 276 hectares and major growing districts also shown similar increasing trend except Bidar as reflected by CAGR for the study period.

The estimated area (2019-20) under cabbage in the major growing districts increased to the tune of 100 hectare in Belagavi, 56 hectare in Haveri, 31 hectare in Chikkaballapura and 11 hectare in Kolardistricts. Positive growth rates attributed for increasing estimated area in these districts. About 8 hectare under cabbage is going to decline in Bidar district as reflected in growth rate.

The incremental area (2019-20) is added or removed (as per CAGR) to the existing area of 2018-19 for all growing districts and state as a whole to arrive estimated demand for cabbage seedling during 2019-20. The estimated demand of cabbage seedling in Karnataka state during 2019-20 for an estimated area of 11263 hectares was 62.57 crores whereas for major growing distracts i.e., 12.97 crores cabbage seedlings required for Belagavi, 10.19 crores for Kolar, 7.17 crores for Haveri, 4.09 crores for Bidar and 3.66 crores for Chikkaballapura. To meet the massive demand for cabbage seedlings, establishment of commercial nurseries are inevitable as these nurseries will provide healthy and vigor seedlings which are basic input for production of any vegetables.

\section{Initial Investment of construction of Shade net house}

The establishment cost on commercial nursery of cabbage seedlings under shade net house condition

Table 1: Estimated demand for cabbage seedlings in Karnataka

\begin{tabular}{cccccc}
\hline Districts & $\begin{array}{c}\text { Area under } \\
\text { Cabbage in } \\
\mathbf{2 0 1 8 - 1 9}(\mathbf{h a})\end{array}$ & $\begin{array}{c}\text { CAGR (\%) in area } \\
\text { from 2010-11 to } \\
\mathbf{2 0 1 8 - 1 9}\end{array}$ & $\begin{array}{c}\text { Increase / Decrease } \\
\text { in area during 2019- } \\
\mathbf{2 0} \text { (ha) }\end{array}$ & $\begin{array}{c}\text { Estimated area } \\
\text { in 2019-20 (ha) }\end{array}$ & $\begin{array}{c}\text { Estimated demand } \\
\text { for Cabbage } \\
\text { seedlings (Crores) }\end{array}$ \\
\hline Belagavi & 2234 & 4.50 & 100 & 2334 & 12.97 \\
Kolar & 1823 & 0.60 & 11 & 1834 & 10.19 \\
Haveri & 1234 & 4.57 & 56 & 1290 & 7.17 \\
Bidar & 745 & -1.12 & -8 & 737 & 4.09 \\
Chikballapura & 627 & 4.97 & 31 & 658 & 3.66 \\
Karnataka total & 10987 & 2.51 & 276 & 11263 & 62.57 \\
\hline
\end{tabular}


given in table 2 . This whole structure includes investment on shade net structure, irrigation pump set, digging bore well \& motor, construction charges, irrigation facilities and other minor assets. The total capital requirement on commercial cabbage nursery activity of $1000 \mathrm{~m}^{2}$ capable of raising 3556 trays (98 seedlings/portray) was ₹ 531953. The Shade net structure alone constituted 57.82 per cent ( $₹$ 307562) of the total investment followed by construction charges sharing 27.46 per cent (₹146098) of total investment. Investment on irrigation facilities was ₹ 46234 accounting 8.94 per percent of total investment. It is necessary to supply water to portrays on daily basis during nursery rising. The nurseries depend on bore well for irrigation purpose. The cost of digging bore well constituted ₹23458 (4.41\%) of the total initial investment. The investment on other miscellaneous accounted around ₹ 8601 (1.62\%). Thus total investment on establishment of cabbage nursery under shade net structure was ₹ 531953. The Dept. of Horticulture, Government of Karnataka (www.horticulture.kar. nic.in) provides 50 per cent subsidy which accounts to ₹ 265977. Hence, the net investment made by entrepreneur in establishing profitable nursery was ₹265977.

Table 2: Investment structure on cabbage nursery in shade net condition ( $1000 \mathrm{~m}^{2} /$ annum)

\begin{tabular}{clcccc}
\hline $\begin{array}{c}\text { Sl. } \\
\text { No. }\end{array}$ & \multicolumn{1}{c}{ Particulars } & $\begin{array}{c}\text { Quantity } \\
\text { (No.) }\end{array}$ & $\begin{array}{c}\text { Rate } \\
\text { (₹) }\end{array}$ & $\begin{array}{c}\text { Value } \\
\text { (₹) }\end{array}$ & $\begin{array}{c}\text { Share } \\
\text { (\%) }\end{array}$ \\
\hline 1 & Borewell & & & 23458 & 4.41 \\
2 & $\begin{array}{l}\text { Irrigation } \\
\text { pumpset }\end{array}$ & & & 46234 & 8.69 \\
3 & $\begin{array}{l}\text { Shade net } \\
\text { structure }\end{array}$ & & & 307562 & 57.82 \\
4 & $\begin{array}{l}\text { Construction } \\
\text { charges }\end{array}$ & & & 146098 & 27.46 \\
5 & $\begin{array}{l}\text { Rose cans/ hose } \\
\text { pipe }\end{array}$ & 4 & 358 & 1432 & 0.27 \\
6 & Knapsack & 1 & 2594 & 2594 & 0.49 \\
& sprayers & & & & \\
7 & Baskets & 6 & 348 & 2088 & 0.39 \\
8 & Spade & 3 & 300 & 900 & 0.17 \\
9 & Pickaxes & 3 & 279 & 837 & 0.16 \\
10 & Sickles & 5 & 150 & 750 & 0.14 \\
11 & Total Investment & & & 531953 & 100.00 \\
12 & Subsidized & & & 265977 & \\
& amount & & & & \\
13 & Net Investment & & & 265977 & \\
\hline
\end{tabular}

Economics of cabbage seedlings under shade net

The economics of commercial nursery of cabbage under shade net condition is depicted in table 3 .

Table 3: Cost \& returns of cabbage seedling production under shade net condition $\left(1000 \mathrm{~m}^{2} /\right.$ annum)

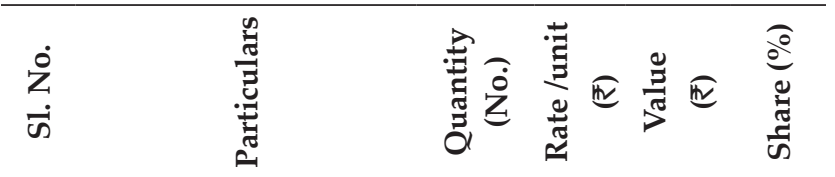

\begin{tabular}{|c|c|c|c|c|c|}
\hline \multicolumn{6}{|c|}{ I. Variable cost $(\mathrm{A})$} \\
\hline 1 & Cabbage seed $(\mathrm{kg})$ & $550 \mathrm{gm}$ & $200 /$ & 11000 & 10.94 \\
\hline 2 & $\begin{array}{l}\text { Protrays with } 98 \text { cells } \\
\text { (no.) }\end{array}$ & 3556 & $\begin{array}{l}\text { gm } \\
8.5 / \\
\text { tray }\end{array}$ & 30226 & 30.05 \\
\hline 3 & Coco peat $(\mathrm{kg})$ & 1456 & 6 & 8736 & 8.68 \\
\hline 4 & Fertilizers $(\mathrm{kg})$ & 25 & 245 & 6125 & 6.09 \\
\hline 5 & PPCs (kg) & 30 & 560 & 16800 & 16.70 \\
\hline 6 & Men labour & 45 & 250 & 11250 & 11.18 \\
\hline 7 & Women labour & 45 & 200 & 9000 & 8.95 \\
\hline 8 & $\begin{array}{l}\text { Interest on working } \\
\text { capital }(8 \%)(₹)\end{array}$ & & & 7451 & 7.41 \\
\hline 9 & Total variable cost (A) & & & 100588 & 100.00 \\
\hline \multicolumn{6}{|c|}{ II. Fixed cost (B) } \\
\hline 10 & Rental value of land (₹) & & 33000 & 30000 & 42.28 \\
\hline 11 & Land revenue (₹) & & 100 & 100 & 0.14 \\
\hline 12 & $\begin{array}{l}\text { Depreciation on } \\
\text { tank, pipe, pump set, } \\
\text { pumphouse, sprayer, } \\
\text { including shade net etc }\end{array}$ & & & 33247 & 46.86 \\
\hline 13 & $\begin{array}{l}\text { Interest on FC (12\%) } \\
(₹)\end{array}$ & & & 7602 & 10.71 \\
\hline 14 & Total fixed cost (B) & & & 70949 & 100.00 \\
\hline 15 & Total cost $(\mathrm{A}+\mathrm{B})=\mathrm{C}$ & & & 171537 & \\
\hline \multicolumn{6}{|c|}{ Returns } \\
\hline 16 & $\begin{array}{l}\text { Cabbage seedlings } \\
\text { trays (no.) }\end{array}$ & 3556 & 70 & 248920 & 100.00 \\
\hline 17 & Gross Income (D) & & & 248920 & 100.00 \\
\hline 18 & Net income $=\mathrm{D}-\mathrm{C}(₹)$ & & & 77383 & \\
\hline 19 & Cost per seedling $(₹)$ & & & 0.49 & \\
\hline 20 & Profit per seedling $(₹)$ & & & 0.22 & \\
\hline
\end{tabular}

The shade net structure installed on $1000 \mathrm{~m}^{2}$ land could accommodate 3556 protrays. The total cost of raising nursery seedling on $1000 \mathrm{~m}^{2}$ worked out to $₹ 171537$. The variable cost constituted ₹ 100587.96 (58.64 \%) and rest was accounted for fixed cost i.e., ₹ 70949 (41.36 \%). The major variable cost was cost of proyrays (₹ 30226), followed by cabbage seeds (11000), labour cost for both men and women 
(₹20250) and coco peat ( $₹$ 8736). Among fixed costs, depreciation on tank, pipe, pump set, pump house, sprayer, including shade net etc was accounted 33247 and interest on fixed capital was worked out at the rate of 12 per cent on investment made by the entrepreneur on commercial cabbage nurseries i.e., ₹ 7602. The rental value of land was accounted 42.28 per cent of total fixed cost ( $₹ 30000$ per year). The gross return from sale of 3556 trays of cabbage seedlings at the rate of ₹ 70 per tray was accounted $₹ 248920$. The net returns obtained was worked out was ₹ 77383. The average cost per seedling worked out to be $₹ 0.49$ and net returns per seedling came to ₹ 0.22. Linganagouda and Mahajanasetti (2016) reported similar results from seedling production under hi-tech condition. Depending up on the demand from farming community, nursery entrepreneur can raise the seedling.

\section{Economic viability of investment cabbage nursery enterprise}

To evaluate the practicability of investment in cabbage nursery, the criteria such as net present worth, benefit cost ratio, payback period and internal rate of return were employed and the results were presented in table 4 .

Table 4: Economic feasibility of investment on cabbage nursery in shade net condition

\begin{tabular}{cc}
\hline $\begin{array}{c}\text { Discounted \& Undiscounted } \\
\text { criterion }\end{array}$ & Magnitude \\
\hline NPV (₹) & 119836 \\
BCR & 1.30 \\
IRR (\%) & 78 \\
PBP & 3.44 \\
\hline
\end{tabular}

Scientific production of cabbage seedlings requires vast investment of ₹265977. Whether the investment on commercial nursery is remunerate or not was examined by employing discounting and undiscounting cash flow procedure (Patil et al. 2017). As indicated by Net Present Worth, the investment on cabbage nursery enterprise under shade net condition generated wealth of ₹ 119836 over its life period duly accounted for inflation. Positive NPW indicated the economic viability of investment in cabbage nursery. Another measure used to judge the viability of investment on project was B:C Ratio which was 1.30 indicating that project generates a returns of 1.30 for every rupee of investment. Similar findings were reported by Ashoka et al. (2017) for investment in jasmine garden.

The value of IRR generally depends on the magnitude of returns realized in each year over the economic life period and more particularly in the initial years of cabbage nursery enterprise. It may be noted here that, the IRR was found to be very high $(78 \%)$, compared to the opportunity cost of capital or rate of interest paid on borrowed capital. Hence, the investment in nursery enterprise was highly profitable, economically feasible and financially sound. Payback period is the period required to recover the initial investment incurred in establishing the garden and in the present study the payback period was found to be 3.44 years. This clearly indicated that it would take four years to recover the entire investment. This could be attributed to the fact that the initial investment itself was lower, besides a higher rate of returns. Patil et al. (2017) reported similar results for investment in tomato nurseries in Karnataka state.

\section{Marketing of cabbage seedlings}

Organized marketing mechanism of cabbage seedling is lacking. The only one marketing channel is existing for marketing of cabbage seedling is nursery entrepreneur cabbage grower.

Table 5: Problems faced by cabbage nursery entrepreneurs

\begin{tabular}{clcc}
\hline $\begin{array}{c}\text { S1. } \\
\text { No. }\end{array}$ & \multicolumn{1}{c}{ Particulars } & $\begin{array}{c}\text { No. of nursery } \\
\text { entrepreneurs }\end{array}$ & Percentage \\
\hline 1 & Water scarcity & 19 & 63.33 \\
2 & Labour availability & 12 & 40.00 \\
3 & Mortality of seedling & 4 & 13.33 \\
4 & Sale of seedlings & 4 & 13.33 \\
5 & Lack of technical & 3 & 10.00 \\
& guidence & 23 & 76.67 \\
6 & Lack of credit facility & 15 & 50.00 \\
7 & $\begin{array}{l}\text { Competition among } \\
\text { nurseries }\end{array}$ & 5 & 16.67 \\
8 & $\begin{array}{l}\text { Pest and Disease } \\
\text { incidence }\end{array}$ & 5 & 50.00 \\
9 & Getting Govt. Subsidy & 15 & \\
\hline
\end{tabular}

\section{Problems in raising and marketing of cabbage seedling}

Even though nursery is a profitable venture, it has 
no exception from the constraints. Opinion survey was conducted about the production and marketing constraints of cabbage seedling and the results were presented in table 5. From the table, it could be observed that, the 76.67 per cent of entrepreneurs have expressed lack of credit facility as major problem. Scarcity of water was found to be second major problems which were expressed by 63.33 per cent of the entrepreneurs. The other problem were tough competition to the tune of 50.00 per cent, labour availability during peak season of operation $(40.00 \%)$, pest \& disease incidence $(16.67 \%)$, mortality of seedling (13.33\%) and difficulty in sale of seedlings (13.33\%) as cabbage seedlings have time bound demand.

\section{CONCLUSION}

Raising the healthy nursery is a specialized technology which requires knowledge and skill about various operations and scientific management of nurseries. In the era of climate change and amplified population in the country the vegetable growers have become highly conscious about prominence of quality seeds or seedlings to meet the demand and get the attractive profit. Cabbage nursery production has become a highly commercialized business, wherein most farmers buy their seedlings from professional entrepreneurs. During 2019-20, the area under cabbage in Karnataka state is going to increase to the tune of 276 hectares and the total area would be 11263 hectares. The forecast of the study indicated that, 62.57 crores of cabbage seedlings are required to cultivate estimated area of 11263 hectares in Karnataka. Nowadays, cabbage farmers prefer the seedling from nurseries rather than rising on their own because of healthy, uniformity and vigor seedling. The time period require to raise the seedling takes 20-25 days. If sudden increase or decrease in demand for the seedlings, nurseries should be able to raise and supply the required number of seedlings at right time. Seedling raising under shade net house was highly economically viable as indicated by net profit per seedling (₹0.22) and it is also supported by capital budgeting techniques i.e., positive net worth, comfortable B:C ratio and good IRR (78\%). Thus, cabbage seedling production under shade net condition was found to be profitable activity gaining interest of eventual entrepreneurs.

\section{REFERENCES}

Anonymous, 2014 Package of practice for vegetable crops, University of Horticultural Sciences, Bagalkot, Karnataka, India.

Ashoka, N., Shrinivasulu, G.B., Anupama, G., Harshavardhan, M. and Kattimani, K.N. 2017. Economic Analysis of Production and Marketing of Jasmine in HyderabadKarnataka Region: A Case in Koppal District, India. Int. J .Cur. Micro \& App. Sci., 6: 1702-1711.

Patil, B.O. and Hosamani, S.B. 2017. Performance of national horticulture mission (NHM) scheme and its impact on horticulture development in Karnataka. J. Farm Sci., 30: 485-490.

Dhaliwal, M. 2017. Cole crops. Handbook of Vegetable Crops, New Delhi. Kalyani Publishers, pp. 148- 176.

Food and Agricultural Organization. 1988. Traditional Food Plants. Food and Agricultural Organization of the United Nations, Rome, Italy.

Linganagouda and Mahajanashetti, S.M. 2016. Economic analysis of vegetable production under hi-tech and field condition. J. Farm Sci., 29: 45-49.

Murthy, D.S., Prabhakar, B.S., Hebbar, S.S., Srinivas, V. and Prabhakar, M. 2009. Economic feasibility of vegetable production under polyhouse: A case study of capsicum and tomato. J. Hort. Sci., 14: 48-52.

Pandiyaraj, P., Yadav, R.K., Vijayakumar, S. and Das, A. 2017. Modern Nursery Raising Systems in Vegetables. Int. J. Agri. Sci., 9: 4889-4892.

Patil, K.R., Adivappar, N., Chinnappa, B. and Manjunatha, G.R. 2017. Economic analysis of commercial tomato nurseries. Journal of Crop $\mathcal{E}$ Weed, 13: 137-141.

Sathyendra Kumar, A.D. and Chandrashekar, H.M. 2015. Production performance of selected horticultural commodities in Karnataka. Int. J. Mgt. Res. and Rev., 5: 669-675.

Sekara, A., Cebul, S. and Kunicki, E. 2007. Cultivated eggplants-Origin, breeding objectives and genetic resources, a review", Folia. Horti., 19: 97-114. 
